\title{
IV. SERVICES AND FUNCTIONS OF THE INTERNATIONAL ASTRONOMICAL UNION
}

This section contains reference information about the permanent services provided by the Union either alone or in conjunction with other organizations. Many services are provided by the individual Commissions, usually through committees and working groups; for example: the preparation of bibliographies, lists of observed or computed data, lists of standards, programmes for coordinated observations, etc. Information about such services is provided before each General Assembly in the Draft Reports of the Commission Presidents, distributed free to all Members. Lists of working groups and committees are, in some cases, included in Commission Reports, Volumes XIIA and XIIB of the Transactions.

\section{A. GENERAL SERVICES PROVIDED BY THE UNION ITSELF}

1. Notations (see also Part 2 of this volume, pages 70 and $\mathrm{I} 16$ )

A comprehensive list of recommended notations was adopted at the sixth General Assembly in Stockholm in 1938 and published in Transactions IAU, 6, 345-355, 1939. Additions and corrections to this list were adopted at subsequent meetings of the Commissions (Transactions $I A U, 7,73,8,70$, and 9,77 ) but no revised list has been issued. Commission 3 (des Notations, des Unités et de l'Économie des Publications) was dissolved in 196r.

Many other recommendations have also been made from time to time by various specialized Commissions of the Union. They are reproduced in the successive volumes of the Transactions.

\section{Bibliography}

Commission 5 (Analyses de Travaux et Bibliographie) co-ordinates bibliographical work in the field of astronomy, which is mainly done by organizations independent of the IAU. The three principal sources of bibliographical material are:

Bulletin signalétique du CNRS (Paris, Centre de Documentation du CNRS, 5 quai Anatole France), mensuel. Tables annuelles des auteurs, table par matières, table alphabétique depuis 1960.

Astronomischer fahresbericht (annuel). Herausg. vom Astronomischen Rechen-Institut in Heidelberg, Berlin, Walter de Gruyter.

Referativnyj Zurnal (Moskva) (mensuel). Académie des Sciences de l'U.R.S.S.

Recommendations as to the form in which bibliographical material (particularly references to scientific literature) should be given, will be found below in Part 2, pages 59 and 105).

\section{Astronomical Telegrams}

Commission 6 (Télégrammes Astronomiques) is responsible for directing the work of the "Central Bureau for Astronomical Telegrams" (see hereafter page 32). The objects of the Bureau are to disseminate, as widely and as quickly as possible, to astronomical observatories and others, information concerning new discoveries (comets, novae, supernovae, lunar and 
planetary phenomena) and data to assist observers (ephemerides, position, etc.). It achieves these objectives by transmitting the information it receives

(i) by telegram

or (ii) by printed circular to subscribers.

All relevant information and standard codification is given below by the Director of the Bureau, Dr O. Gingerich (see page 32).

\section{Publications}

A list of IAU publications is given in Part $\mathbf{I}$, page 39. Details of current publications are given regularly in the IAU Information Bulletins which are distributed to Members two or three times a year.

\section{Information regarding astronomers and observatories}

Current literature contains data on the main astronomical instruments, but does not, however, supply information concerning the scientific, technical and administrative evolution of the observatories.

In addition to the list of the names and addresses of IAU Members (see below Part 3, page 16I) the IAU has sponsored, under the supervision of Commission 5, the publication of the volume Les Observatoires astronomiques et les Astronomes, prepared and published by l'Observatoire Royal de Belgique in 1959. This volume contains a list of astronomical observatories and their staff and equipment. Copies may be obtained on application to the IAU Assistant Secretary.

Obviously such a publication becomes obsolete very rapidly; for this reason l'Observatoire Royal de Belgique is now preparing, under the auspices of Commission 5, a revised version of this publication in the form of loose sheets.

\section{The Exchange of Astronomers}

In 1946 the IAU created Commission no. 38 for the Exchange of Astronomers to facilitate visits of astronomers, for purposes of study and research, to institutes abroad. This Commission is directed by a president, a vice-president and an organizing committee, in the same way as the other IAU Commissions, but since 1964 this Commission (together with the administrative Commissions 5 and 6 ) is now regarded as a Committee of the Executive Committee.

From the funds allocated by the General Assembly, the Commission allocates grants to professional astronomers, generally at post-doctorate level, to enable them to continue their work in countries other than their own. Some wish to work with instruments not available in their own country, others to consult plate collections, and others to have the stimulus of theoretical discussions with other specialists. In the past, grants have generally covered only travel expenses; it is assumed that, for the costs of living, funds from other sources will be found, or that an assistantship may be obtained. In some exceptional cases the reverse is followed, the Union paying living, rather than travel, expenses. Grants are available for any period of time, provided the duration of the visit is sufficient to permit effective scientific results. Co-operation between the northern and the southern hemispheres and between eastern and western countries is especially encouraged.

Applications should be sent to the President of the Commission, Professor M. G. J. Minnaert, Sterrewacht "Sonnenborgh", Zonnenburg 2, Utrecht, The Netherlands, and should include information about the purpose and duration of the visit, a note from the Director of the home observatory and another from the Director of the host observatory (confirming that the visit is approved), an estimate of the travel expenses required, the address to which the money should 
be sent, and the date by which it is required. Most applications are answered quickly and positively.

At the end of the visit, the President of Commission $3^{8}$ requests a short report on the work which has been carried out.

At the 1964 meeting of Commission 38 it was decided to extend the work of the Commission to older students, who have a master's degree (or an equivalent diploma) and who wish further training in astronomy, or who are in the process of preparing their thesis. For this purpose, a special sub-committee was formed under the direction of the Vice-President. This might be of special interest to students in the newly developing countries.

The Commission keeps an up-to-date list of astronomical institutes at which facilities or scholarships are available for astronomers from abroad (see the Transactions of the IAU and the Information Bulletins).

\section{B. SPECIFIC PROJECTS}

\section{The System of Astronomical Constants}

The Executive Committee set up a working group on the system of astronomical constants whose report was adopted at the twelfth General Assembly (see Transactions $I A U$, volume XIIB, page 593). In view of the importance of this recent work, closely related to the activities of Commission 7 of the IAU, the new reference list of recommended constants is reproduced below.

\section{Notes on the constants}

I. The value given for the number of ephemeris seconds in the tropical year at 1900 is taken from the definition of the ephemeris second that was adopted by the Comite International des Poids et Mesures (Procès Verbaux des Séances, deuxième série, 25, 77, 1957). It is, in fact, derived from the coefficient of $T$, measured in Julian centuries of $3_{3} 625$ days, in Newcomb's expression for the geometric mean longitude of the Sun referred to the mean equinox of date. In the list "Ig00" refers to the fundamental epoch of ephemeris time, namely I 900 January o at $2^{\mathrm{h}}$ E.T., or to $1900 \cdot 0$, as appropriate; the values for constants $20-23$ also refer to the fundamental epoch. Throughout the list and this report the term "second" must be understood to mean the "ephemeris second".

2. The value of the Gaussian gravitational constant $(k)$ is that adopted by the IAU in $193^{8}$, and serves to define the astronomical unit of length (A.U.) since the corresponding (astronomical) units of mass and time are already defined. (The unit of mass is that of the Sun and the unit of time is the ephemeris day of 86400 ephemeris seconds. The units of $k$ are: (A.U.) (ephemeris day) ${ }^{-1}$ (Sun's mass) ${ }^{-\frac{1}{2}}$.) To simplify the later equations an auxiliary constant $k^{\prime}$, defined as $k / 86400$, is introduced and a rounded value is given in the list.

3. The value for the measure of the A.U. in metres is a rounded value of recent radar determinations.

4. The value for the velocity of light is that recommended by the International Union of Pure and Applied Physics in September 1963.

5. The term "equatorial radius for Earth" refers to the equatorial radius of an ellipsoid of revolution that approximates to the geoid. (See also note r6.)

6. The term "dynamical form-factor for Earth" refers to the coefficient of the second harmonic in the expression for the Earth's gravitational potential as adopted by IAU Commission 7 in $196 \mathrm{I}$. (See also note 16 .)

7. The geocentric gravitational constant $(G E)$ is appropriate for use for geocentric orbits when the units of length and time are the metre and the second; $E$ denotes the mass of the 


\section{Reference list of recommended constants}

Defining constants: Constantes de définition

I. Number of ephemeris seconds in I tropical year (I900)

Nombre de secondes de temps des éphémérides pour

$s=3^{1} 55^{6} 9^{2} 5^{\circ} 9747$

l'année tropique (1900)

2. Gaussian gravitational constant, defining the A.U.

Constante de la gravitation universelle, définissant

l'unité astronomique (U.A.)

Primary constants: Constantes primaires

3. Measure of the A.U. in metres

Longueur de l'u.A. en mètres

$k=0.01720209895$

4. Velocity of light in metres per second

Vitesse de la lumière, en mètres par seconde

$$
\begin{aligned}
A & =149600 \times 10^{6} \\
c & =299792.5 \times 10^{3} \\
a_{\mathrm{e}} & =6378 \mathrm{I} 60 \\
\mathscr{f}_{2} & =0.0010827
\end{aligned}
$$

5. Equatorial radius for Earth in metres

Rayon équatorial terrestre, en mètres

6. Dynamical form-factor for Earth

Facteur d'ellipticité géopotentielle

7. Geocentric gravitational constant (units: $\mathrm{m}^{3} \mathrm{~s}^{-2}$ )

Constante géocentrique de la gravitation

$$
G E=398603 \times 10^{9}
$$

8. Ratio of the masses of the Moon and Earth Rapport de la masse de la Lune à celle de la Terre

$$
\mu=\mathrm{I} / 8 \mathrm{I} \cdot 30
$$

9. Sidereal mean motion of Moon in radians per second (I900)

Moyen mouvement sidéral de la Lune en radians par

$n^{*}=2 \cdot 66 \mathrm{I} 699489 \times 10^{-6}$ seconde (1900)

IO. General precession in longitude per tropical century (1900)

Précession générale en longitudes par siècle tropique

$$
p=5025^{\prime \prime} \cdot 64
$$
(1900)

II. Obliquity of the ecliptic (1900)

Obliquité de l'écliptique (r900)

$$
\epsilon=23^{\circ} 27^{\prime} \circ 8^{\prime \prime} \cdot 26
$$

12. Constant of nutation (1900)

Constante de la nutation (1900)

$$
N=9: 210
$$

\section{Auxiliary constants and factors}

$k / 86400$, for use when the unit of time is I second

Number of seconds of arc in I radian

Factor for constant of aberration (note 15 )

Factor for mean distance of Moon (note 20)

$$
\begin{aligned}
k^{\prime}= & \mathrm{I} \cdot 990983675 \times \mathrm{IO}^{-7} \\
& 206264.806 \\
F_{1}= & \mathrm{I} \cdot 000 \mathrm{I} 42 \\
F_{2}= & 0.999093 \mathrm{I} 42 \\
F_{3}= & 49853^{\prime \prime 2}
\end{aligned}
$$




\section{Reference list of recommended constants (continued)}

Derived constants: Constantes secondaires

13. Solar parallax

Parallaxe solaire

$$
\begin{aligned}
\arcsin \left(a_{\mathrm{e}} / A\right) & =\pi_{\odot}=8^{\prime \prime} 79405\left(8^{\prime \prime} 794\right) \\
A / c=\tau_{\mathrm{A}} & =499.0 \mathrm{I} 2 \\
& =\mathrm{I}^{\mathrm{s}} / 0.00200396 \\
F_{1} k^{\prime} \tau_{\mathrm{A}} & =\kappa=20^{\prime \prime} .4958\left(20^{\prime \prime} 496\right) \\
f & =0.00335^{2} 9 \\
& =\mathrm{I} / 298.25
\end{aligned}
$$

Temps de lumière relatif à l'v.A.

Constante de l'aberration

17. Heliocentric gravitational constant (units: $\mathrm{m}^{3} \mathrm{~s}^{-2}$ ) Constante héliocentrique de la gravitation

$$
A^{3} k^{2}=G S=13^{2} 718 \times 10^{15}
$$

18. Ratio of masses of Sun and Earth

Rapport de la masse du Soleil à celle de la Terre

$$
(G S) /(G E)=S / E=33^{2} 95^{8}
$$

19. Ratio of masses of Sun and Earth + Moon

Rapport de la masse du Soleil à celle du

$$
S / E(1+\mu)=3289 \text { г } 2
$$
système Terre-Lune

20. Perturbed mean distance of Moon, in
metres
Demi-grand axe perturbé de l'orbite de $F_{2}\left(G E(\mathrm{r}+\mu) / n_{\mathbb{Q}}^{* 2}\right)^{1 / 3}=a_{\llbracket}=384400 \times 10^{3}$ la Lune, en mètres

21. Constant of sine parallax for Moon

Sinus de la parallaxe de la Lune

22. Constant of lunar inequality

Constante de l'inégalité lunaire

$$
\begin{aligned}
& a_{\mathrm{e}} / a_{\varangle}=\sin \pi_{৫}=3422^{\prime \prime} 45^{\mathrm{I}} \\
& \frac{\mu}{\mathrm{I}+\mu} \frac{a_{\S}}{A}=L=6 " 43987(6 " 440)
\end{aligned}
$$

23. Constant of parallactic inequality

Constante de l'inégalité parallactique

$$
\mathrm{F}_{3} \frac{\mathrm{I}-\mu}{\mathrm{I}+\mu} \frac{a_{\S}}{A}=P_{\varsigma}=124: 986
$$

\section{System of planetary masses}

24. Mercury

Venus

Earth + Moon

Mars
Reciprocal mass

$$
\begin{array}{r}
6000000 \\
408000 \\
329390 \\
3093500
\end{array}
$$

Jupiter

Saturn

Uranus

Neptune

Pluto
Reciprocal mass

$1047 \cdot 355$
$3501 \cdot 6$
22869
19314
360000


Earth including its atmosphere. Kepler's third law for a body of mass $M$ moving in an unperturbed elliptic orbit around the Earth may be written

$$
G E(\mathrm{I}+M / E)=n^{2} a^{3}
$$

where $n$ is the sidereal mean motion in radians per second and $a$ is the mean distance in metres. The value of $G E$ is based on gravity measurements and observations of satellites.

8. Again the mass of Earth includes the mass of the atmosphere. The reciprocal of $81 \cdot 30$ is $0.012300 \mathrm{I}$.

9. The value for the sidereal mean motion of the Moon is consistent with the value of the tropical mean motion used in the improved lunar ephemeris, less the general precession in longitude.

IO-I2. The values of the principal constants defining the relative positions and motions of the equator and ecliptic are those in current use. Secular terms and derived quantities are already tabulated elsewhere.

13. The rounded value 8"794 for the solar parallax should be used except where extra figures are required to ensure numerical consistency.

14. The value of the light-time for unit distance is numerically equal to the number of lightseconds in I A.U. Its reciprocal is equal to the velocity of light in A.U. per second.

15. Apart from the factor $F_{1}$ the constant of aberration is equal to the ratio of the speed of a hypothetical planet of negligible mass moving in a circular orbit of unit radius to the velocity of light; it is conventionally expressed in seconds of arc by multiplying by the number of seconds of arc in one radian. The factor $F_{1}$ is the ratio of the mean speed of the Earth to the speed of the hypothetical planet and is given by

$$
F_{1}=\frac{n_{\odot}}{k^{\prime}} \frac{a_{\odot}}{\left(\mathrm{I}-e^{2}\right)^{1 / 2}}
$$

where $n_{\odot}$ is the sidereal mean motion of the Sun in radians per second, $a_{\odot}$ is the perturbed mean distance of the Sun in A.U., and $e$ is the mean eccentricity of the Earth's orbit. Newcomb's values for $n_{\odot}, a_{\odot}$ and $e$ are of ample accuracy for this purpose. The factor $F_{1}$ and the constant of aberration take the following values

$\begin{array}{ccc} & F_{1} & \kappa^{\prime \prime} \\ 1800 & \text { I.000 I42 } 7 & 20.49583 \\ \text { I900 } & \text { I.000 I42 O } & 20.49582 \\ 2000 & 1.000 \text { I4I 3 } & 20.4958 \text { I }\end{array}$

The rounded value $20^{\prime \prime} 496$ should be used except where the extra figures are required to ensure numerical consistency.

16. The condition that the reference ellipsoid of revolution for the Earth shall be an equipotential surface implies that three parameters are sufficient to define its geometrical form and external gravitational field, provided that the angular velocity $(\omega)$ of the Earth and the relative mass of the atmosphere $\left(\mu_{\mathfrak{a}}\right)$ are assumed to be known. The variability of the rate of rotation of the Earth can be ignored, and the mass of the atmosphere is only just significant; the required values are:

$$
\omega=0.00007292 \mathrm{I} \text { radians per second; } \mu_{\mathrm{a}}=0.00000 \mathrm{I}
$$

The expressions for the flattening $(f)$ and the apparent gravity at the equator $(g \mathrm{e})$ in terms of the primary constants are, to second order:

$$
\begin{aligned}
& f=\frac{3}{2} \mathfrak{F}_{2}+\frac{1}{2} m+\frac{9}{8} \mathfrak{F}_{2}^{2}+\frac{1}{2} \frac{5}{8} \mathfrak{F}_{2} m-\frac{39}{5} m^{2} \\
& g_{\mathrm{e}}=\left(G E / a_{\mathrm{e}}^{2}\right)\left(\mathrm{r}-\mu_{\mathrm{a}}+\frac{3}{2} \mathcal{F}_{2}-m+\frac{27}{9} \mathcal{F}_{2}^{2}-\frac{6}{7} \mathcal{F}_{2} m+\frac{4}{5} \frac{7}{6} m^{2}\right)
\end{aligned}
$$

where $m=a_{\mathrm{e}} \omega^{2} / g_{\mathrm{e}}$ is obtained by successive approximations. The new value of $f$ is given here only for astronomical use (parallax corrections, etc.). 
I7. The heliocentric gravitational constant corresponds to $G E$, but is appropriate for heliocentric orbits when the units are the metre and the second.

I 8-I9. The derived values of the masses of the Earth and of the Earth + Moon differ from those currently in use, but will not supersede them completely until the system of planetary masses is revised as a whole. (See note 24.)

20. The perturbed mean distance of the Moon is the semi-major axis of Hill's variational orbit, and differs from that calculated from Kepler's law by the factor $F_{2}$, which depends on the well-determined ratio of the mean motions of the Sun and Moon. (E. W. Brown, Mem. R. astr. Soc., 53, 89, I 897).

21. The constant of sine parallax for the Moon is conventionally expressed in seconds of arc by multiplying by the number of seconds of arc in one radian. The corresponding value of $\pi_{8}$ itself is $3422 \% 608$.

22. The constant of the lunar inequality is defined by the expression given and is conventionally expressed in seconds of arc.

23. The constant of the parallactic inequality is defined by the expression given; the coefficient $F_{3}$ is consistent with the corresponding quantities in Brown's Tables.

24. The system of planetary masses is that adopted in the current ephemerides and the values given for the reciprocals of the masses include the contributions from atmospheres and satellites. The value for Neptune is that adopted in the numerical integration of the motions of the outer planets; the value used in Newcomb's theories of the inner planets is 19700 . In planetary theory the adopted ratio of the mass of the Earth to the mass of the Moon is $8 \mathrm{I} \cdot 45$ (compared with $8 \mathrm{r} .53$ in the lunar theory), and the ratio of the mass of the Sun to the mass of the Earth alone is 333432 . This system of masses should be revised within the next few years when improved values for the inner planets are available from determinations based on space-probes.

\section{Correction factors and limits}

To first order, relative errors of the derived constants are given by:

$$
\begin{aligned}
& \frac{\Delta \pi_{\odot}}{\pi_{0}}=\frac{\Delta a_{\mathrm{e}}}{a_{\mathrm{e}}}-\frac{\Delta A}{A} \quad \frac{\Delta \tau_{\mathrm{A}}}{\tau_{\mathrm{A}}}=\frac{\Delta A}{A}-\frac{\Delta c}{c} \\
& \frac{\Delta \kappa}{\kappa}=\frac{\Delta A}{A}-\frac{\Delta c}{c}=\begin{array}{c}
\Delta \tau_{\mathrm{A}} \\
\tau_{\mathrm{A}}
\end{array} \quad \frac{\Delta f}{f}=\frac{\Delta \mathscr{F}_{2}}{\mathfrak{F}_{2}} \\
& \frac{\Delta(G S)}{G S}=\frac{3^{\Delta A}}{A} \quad \frac{\Delta(S / E)}{S / E}=-\frac{\Delta(G E)}{G E}+\frac{3^{\Delta A}}{A} \\
& \frac{\Delta\{S / E(\mathrm{I}+\mu)\}}{S / E(\mathrm{I}+\mu)}=\frac{3 \Delta A}{A}-\frac{\Delta(G E)}{G E}-\frac{\Delta \mu}{\mathrm{I}+\mu}
\end{aligned}
$$

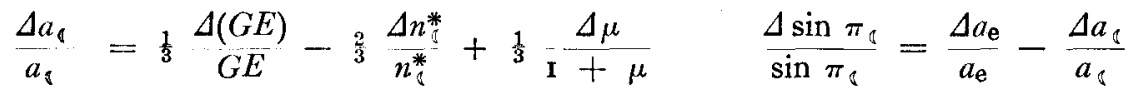

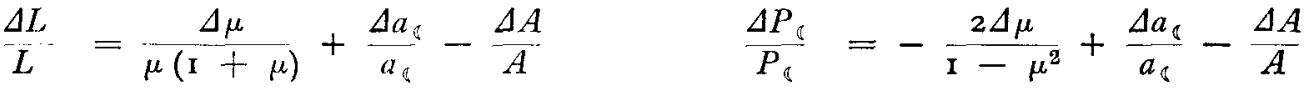

The true values of the primary constants are believed to lie between the following limits:

$$
\begin{aligned}
& A \text { : } \quad 149597 \text { to } 149601 \times 10^{6} \mathrm{~m} \\
& c \text { : } 299792 \text { to } 299793 \times 10^{3} \mathrm{~m} \mathrm{~s}^{-1} \\
& a_{\mathrm{e}} \text { : } 6378 \circ 80 \text { to } 6378240 \mathrm{~m} \\
& \mathcal{F}_{2}: 0.0010824 \text { to } 0.0010829 \\
& G E: \quad 398600 \text { to } 398606 \times \mathrm{IO}^{9} \mathrm{~m}^{3} \mathrm{~s}^{-2} \\
& \begin{array}{l}
\mu^{-1}: \quad 8 \mathrm{I} \cdot 29 \text { to } 8 \mathrm{I} \cdot 3 \mathrm{I} \\
n^{*}: \text { : } \\
p:: 5026^{\prime \prime} 40 \text { to } 5026^{\prime \prime} 90 \\
\epsilon: 3^{\circ} 27^{\prime} \circ 8^{\prime \prime} \mathrm{I} 6 \text { to } \ldots \circ 8^{\prime \prime} 3^{6} \\
N: 9^{\prime \prime 2} 200 \text { to } 9^{\prime \prime} 210
\end{array}
\end{aligned}
$$


Correspondingly the limits for the derived constants are:

\begin{tabular}{|c|c|c|c|c|}
\hline$\pi_{0}$ & : & $8^{\prime \prime} 79388$ to $8^{\prime \prime} 79434$ & $f^{-1}$ & $298 \cdot 33$ to $298 \cdot 20$ \\
\hline$\tau_{\mathrm{A}}$ & : & 499 .00I to 499 \% 6 & & $3^{8} 4399$ to $3^{84} 401 \times 10^{3} \mathrm{~m}$ \\
\hline$\kappa$ & : & $20 " 4954$ to $20 " 4960$ & $\sin \pi_{\mathbb{Q}}:$ & $3422 " 397$ to $3422 " 502$ \\
\hline$G S$ & : & 132710 to $13272 \mathrm{r} \times 10^{15} \mathrm{~m}^{3} \mathrm{~s}^{-2}$ & $L$ & $6 " 4390$ to $6^{\prime \prime} 4408$ \\
\hline $\begin{array}{l}S / E \\
S / E(1\end{array}$ & : & $\begin{array}{l}332935 \text { to } 332968 \\
328890 \text { to } 328922\end{array}$ & $P_{\bullet}$ & $124 " 984$ to $124 " 989$ \\
\hline
\end{tabular}

\section{Heliographische Karten der Photosphäre (a project supported by Commission 10)}

Heliographic maps of the photosphere were prepared at the Swiss Federal Observatory, Zürich, from 1887 to 1898 . During the following years only the results were published, but not the maps. However, as from 1926 the maps have been published annually, first in the Astronomische Mitteilungen der Eidgenössischen Sternwarte, and since 1939 in the Publikationen der Eidgenössischen Sternwarte. Until the year 1945 the Heliographische Karten der Photosphäre were based on observations made at the Swiss Federal Observatory with few contributions from other observatories; therefore these early maps are not without gaps. Since the establishment of the two branch stations of the Swiss Federal Observatory in Arosa and Locarno, sunspot data have been available for about $35^{\circ}$ days each year. The remaining days are covered by numerous stations, among which should be mentioned those of Istanbul, Potsdam, Uccle, Kanzelhöhe, Bucharest, Madrid and Skalnaté Pleso. Through this international co-operation the observations on which the Heliographische Karten der Photosphäre are based have been complete since 1945 .

For each rotation period the maps give drawings of the plage-regions and the sunspot groups at their maximum development. Tables describing the development from day to day of each sunspot group are added to each map. From the maps and tables together it is possible to ascertain, for every day, how many spot groups occurred, the phase of their development, and their distribution on the solar disk.

Further information can be obtained from Professor M. Waldmeier, Direktor der Eidgenössischen Sternwarte, Schmelzbergstrasse 25, Zürich 6, Switzerland.

\section{Cartes Synoptiques de la Chromosphère Solaire. Catalogues des Filaments et des Centres d'Activité (entreprise appuyée par la Commission го)}

Cette publication est préparée depuis I919 par l'Observatoire de Paris-Meudon, sous les auspices de l'UAI et avec son concours financier. Elle a pour but de réunir une documentation permanente sur les centres d'activité (avec ou sans taches), tels qu'on peut les identifier sur les spectrohéliogrammes de la raie $\mathrm{K}$ de $\mathrm{Ca}$ II, et sur les filaments et protubérances vus surtout en $\mathrm{H} \alpha$.

Au cours des années, le contenu exact de la publication a plusieurs fois été modifié dans certains détails. Il est actuellement le suivant:

(a) Cartes synoptiques. Une carte est établie pour chaque rotation de Carrington, donnant les positions et caractéristiques des taches, plages et filaments. Les conventions graphiques adoptées rendent compte de la dimension maximum des taches (au-delà d'un certain seuil) du contour et de la brillance des plages, de la longueur, de la forme et de la persistance des filaments.

(b) Catalogue des centres actifs. Ce catalogue a l'ambition d'être complet. Il donne des indications permettant de reconstituer approximativement l'évolution du centre au cours de son passage dans l'hémisphère visible, et d'identifier les récurrences d'une rotation à l'autre. 
(c) Catalogue des filaments. Il contient seulement les filaments d'une certaine stabilité, vus pendant plus d'un jour, et donnent certains renseignements sur leur évolution, ainsi que la possibilité d'identifier les récurrences.

Les cartes synoptiques et les catalogues sont préparés à l'aide de clichés provenant de plusieurs observatoires de divers pays. Ils sont publiés tous les deux ans, le dernier fascicule paru couvrant la période $1962-63$. Leur distribution, gratuite grâce à une subvention de l'UAI, s'étend à tous les observatoires et bibliothèques universitaires.

Tout renseignement complémentaire peut être obtenu en s'adressant à M. R. Michard, Observatoire de Meudon, 5 place Janssen, 92-Meudon, France.

\section{The Minor Planet Center (a project supported by Commission 20)}

The principal function of the International Astronomical Union Minor Planet Center at Cincinnati is to publish and distribute the Minor Planet Circulars. These consist primarily of: (i) observations of minor planets, (ii) results of orbit improvements, with residuals, and (iii) ephemerides of unnumbered minor planets or others which are more recent than have been published in the annual I.T.A. volume of ephemerides from Leningrad. The following dates indicate the rate of publication: MPC 500 in April 1951, 1953, MPC 1500 in October 1956, and MPC 2000 in May 1960. The Minor Planet Center maintains a punched-card index (now approximately 75000 cards) of one card for each minor planet observation made since 1939, and earlier ones which have been used in the Center's automatic differential correction procedures. With the aid of these, the solar coordinates, including topocentric corrections, may be interpolated automatically. The positions of the stars in the AGK2 from $+90^{\circ}$ to $+30^{\circ}$, the Yale Zones from $+30^{\circ}$ to $-30^{\circ}$, and the Cape Zones below this, are all recorded on magnetic tape. Electronic computer programmes exist for plate reductions, provided the measures have been made in accordance with the method of dependences, and recorded in a specific format. Such reductions are now being computed regularly for several observatories.

Further particulars can be obtained from Dr P. Herget, Cincinnati Observatory, Ohio 45208, U.S.A.

\section{Centres de Documentation Photographique Planétaire de l'Union Astronomique Internationale}

Par suite de l'importance des travaux en physique planétaire, accrue après le récent développement de la science de l'espace, la Commission I6 de l'UAI, au cours de la onzième Assemblée Générale tenue à Berkeley en I96I, par sa Résolution 3 (voir Transactions $I A U, \mathbf{X I B}, \mathrm{p} .245$ ) a fondé deux Centres de Documentation Photographique Planétaire, l'un aux Etats-Unis, à l'Observatoire Lowell, Flagstaff (Arizona), et l'autre en Europe, à l'Observatoire de Meudon, 92-Meudon, France.

Le but de ces Centres est de réunir le plus grand nombre possible de documents photographiques planétaires existant dans le monde, de les classer selon leur qualité et leur possibilité d'usage et de les mettre à la disposition des chercheurs.

Les documents réunis aux deux Centres sont disponibles sous forme

(a) de clichés négatifs originaux contenant 20 à 40 images planétaires par cliché,

(b) d'images positives compositées sur verre et de négatifs correspondants sur film,

(c) de contre-types positifs de clichés originaux agrandis ou non,

(d) de négatifs originaux sur film,

(e) de positifs tirés sur papier.

Le nombre total de documents existant actuellement, sous toutes les formes précitées, est pour le Centre de Lowell d'environ $5_{5}$ 000, et pour le centre de Meudon d'environ 8500. 
Il est prévu que les clichés seront évalués, catalogués, selon leur date T.U., la longueur d'onde utilisée, la résolution et la qualité de grain du cliché, le nombre de bonnes images sur chaque cliché, l'existence ou non de calibration, l'usage possible, i.e. compositage, photométrie, et mesures concernant diamètres, triangulations de la surface, temps de rotation, les données résultant étant transférées sur des cartes perforées I.B.M.

Des documents recueillis aux deux Centres ont été utilisés par des spécialistes pour l'étude

(a) de la topographie et des phénomènes saisonniers de la Planète Mars;

(b) des phénomènes atmosphériques et de la rotation de Vénus;

(c) de l'activité atmosphérique de Jupiter et de Saturne, des nuages jaunes de Mars, etc.

Des travaux concernant les nuages de Mars photographiés dans des longueurs d'onde courte et la topographie de cette Planète pour la période r905-1939 sont en cours.

Les observatoires ou les stations participant à l'échange de documents avec les deux Centres ou à la coopération internationale pour l'observation des Planètes sont les suivants:

Europe: Athènes, Gênes, Juvisy, Nice, Meudon, Pic du Midi, St Michel;

Afrique: Brazzaville, Johannesburg;

U.R.S.S.: Kiev, Volgograd;

Japon: Kwasan, Tokyo;

U.S.A.: Harvard, Lick, Lowell, Mount Wilson, New Mexico, Table Mountain, Tucson.

Tout renseignement complémentaire peut être obtenu en s'adressant directement à Messieurs A. Dollfus (Observatoire de Meudon, 92-Meudon, France) et J. S. Hall (Director of the Lowell Observatory, Flagstaff, Arizona, U.S.A.).

\section{Carte Photographique du Ciel (Commission 23)}

Les travaux de la Carte Photographique du Ciel se sont développés comme suit:

(a) Catalogue photographique. Calculs

L'impression du catalogue photographique est maintenant terminée.

Les astronomes possèdent donc les coordonnées rectilignes mesurées $x, y$ de toutes les étoiles du catalogue.

Le catalogue ne sera utile que si les constantes de chaque cliché sont calculées afin de pouvoir passer des $x, y$ aux coordonnées équatoriales $\alpha, \delta$. Les coordonnées équatoriales et les mouvements propres des étoiles repères servant au calcul des constantes seront déduits des catalogues $\mathrm{AGK}_{2}$ et $\mathrm{AGK}_{3}$. L'Observatoire de Bergedorf possède toutes les données sur cartes perforées et à l'unanimité les membres de la Commission 23 ont accordé toute leur confiance à MM. Kox et Dieckvoss pour mener à bien tous les calculs. A priori on peut se demander s'il est utile de posséder les $\alpha, \delta$ de toutes les étoiles pour une époque voisine de i900. Il faut répondre par l'affirmative à cette question, car les positions obtenues permettront l'amélioration des mouvements propres des étoiles repères.

(b) Observations conseillées aux observateurs possédant un équatorial photographique du type de la Carte du Ciel (liste donnée à titre indicatif)

(i) Nébuleuses extragalactiques du programme de Deutsch: Si l'on admet que les mouvements propres des nébuleuses sont nuls, il est possible de déterminer les mouvements propres des étoiles. Il suffit de photographier une région du ciel à deux époques différentes, par exemple à 25 ans d'intervalle. De telles déterminations ont été entreprises à Lick, Yale, Poulkovo, Moscou, Kiev, Tachkent, etc.

(ii) Astéroïdes: L'observation photographique des astéroïdes est plus précise que l'observation du Soleil et des grosses planètes. Si la théorie du mouvement d'astéroïdes choisis est établie, 
leur observation permettra les corrections systématiques des catalogues d'étoiles, la correction de la constante de précession et la résolution de problèmes importants de l'astronomie fondamentale. Ont notamment abordé ces problèmes: Zverev (catalogue des étoiles faibles en tant que problème astrométrique, congrès de l'UAI à Moscou), Brouwer, etc.

(iii) Mouvements propres des étoiles variables du programme de Groningue: les mouvements propres seront calculés à partir des positions et des mouvements propres d'étoiles repères donnés à l'AGK2 et l'AGK 3 (Bergedorf).

Tout renseignement complémentaire peut être obtenu en s'adressant directement au Président de la Commission 23, M. P. Sémirot, Directeur de l'Observatoire de Bordeaux, Floirac, Gironde, France.

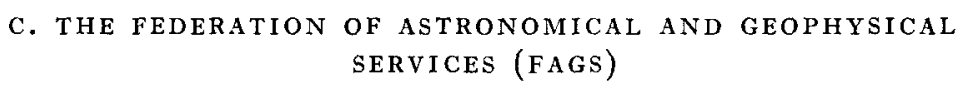

The Federation of Astronomical and Geophysical Services (FAGS) is constituted under the auspices of the ICSU; its purpose is to bring under one organization the permanent services of interest to astronomy, geodesy, geophysics, and neighbouring sciences. A "permanent service" is an organization sponsored by one or more scientific members of the ICSU and responsible for

(i) gathering, in a continuous way, observations and data related to the sciences of astronomy, geodesy and geophysics;

(ii) analysing and synthetizing such observations and data;

(iii) drawing conclusions from such analyses;

(iv) providing data on request;

(v) providing on request, or publishing, all obtained results.

In addition to the services of direct interest to astronomy or astrophysics, described in detail below, the following services are federated in FAGS:

Service Permanent des Indices Géomagnétiques (IUGG), Portosa, Utrecht, Göttingen (Director: Professor J. Veldkamp).

Bureau Gravimétrique International (IUGG), Paris (Director: Professor P. Tardi).

International Seismological Summary (IUGG), Edinburgh (Director: Dr P. Willmore).

Bulletin Mensuel du Bureau Seismologique International (IUGG), Strasbourg (Director: Professor J. P. Rothé).

Permanent Service for Mean Sea Level (IUGG), Liverpool (Director: Dr J. R. Rossiter).

Service Permanent des Marées Terrestres (IUGG), Uccle (Director: Dr P. Melchior).

Permanent Service on Crustal Thickness (IUGG), Toronto (Director: Professor J. Tuzo Wilson).

Solar Particles And Radiations Monitoring Organization (SPARMO) (Director: J.-P. Legrand, Laboratoire de Physique Cosmique, 2 rue des Vertugadins, 92-Meudon, France).

Under consideration: Permanent Service on the Fluctuation of Glaciers.

Any further information can be obtained from Professor G. D. Garland, General Secretary of FAGS, Geophysical Laboratory, University of Toronto, Toronto 5, Ontario, Canada, or preferably from the scientific secretary, Dr A. F. Moore, 2 via Sebenico, Rome, Italy.

The services of interest to astronomy are the following:

\section{Le Bureau International de l'Heure (BIH)}

Adresse: Observatoire de Paris, 6r avenue de l'Observatoire, Paris-I4e, France.

Directeur: J.-F. Denisse.

Chef des Services: B. Guinot. 
Fondé en 1919, d'après les propositions du Général Ferrié, le Bureau International de l'Heure (BIH) a ses statuts fixés par un réglement d'ordre intérieur adopté à l'Assemblée Générale de l'UAI, à Leyde, en 1928 (voir Transactions $I A U, 4,304$, 1932), et en cours de modification.

Les tâches du BIH ont évolué depuis; actuellement ce service, qui est un service permanent de FAGS, se conforme aux recommandations de l'UAI, de l'UGGI, du CCIR, et de l'URSI.

Le BIH doit calculer la meilleure valeur de l'heure en temps universel (T.U. 2) à attribuer aux instants d'émission de signaux horaires. Pour cela, il centralise l'ensemble des observations astronomiques de l'heure et des réceptions de signaux faits dans le monde entier (actuellement les résultats de plus de 40 services horaires sont utilisés). Les travaux nécessitent la discussion des mesures de latitude afin d'en déduire les corrections de longitude à appliquer pour tenir compte du déplacement du pôle.

Par intégration des fréquences des étalons atomiques, le BIH construit une échelle de temps atomique qu'il compare au T.U. 2.

Les principaux signaux horaires sont maintenant liés au temps atomique, et de plus, leurs temps d'émission sont coordonnés. Le BIH a la charge de déterminer, en consultation avec les observatoires intéressés, les décalages de fréquences et les sauts à faire subir aux émissions, afin que les signaux horaires restent approximativement en accord avec le T.U. 2. Le BIH annonce les décisions prises.

Les résultats des travaux du BIH sont publiés dans le "Bulletin Horaire", qui paraît à raison de deux fascicules tous les deux mois. La distribution du "Bulletin Horaire" est gratuite, sur demande adressée au Directeur du BIH. L'un des fascicules donne l'heure demi-définitive, qui est basée uniquement sur les observations et réceptions faites à Paris. L'autre contient l'heure définitive qui résulte de la discussion générale des données de l'ensemble des services horaires.

\section{Central Bureau of the International Polar Motion Service}

Address: International Latitude Observatory, Mizusawa-shi, Iwate-ken, Japan.

Director: Dr S. Yumi.

This service, formerly known as the International Latitude Service, was created in 1895 for the determination of the motion of the pole of the Earth's rotation, which causes variations in the latitude of each point on the Earth. Five special observatories were originally set up on the parallel of latitude N. $39^{\circ} \circ 8^{\prime}$ and commenced their observational programmes in 1899 . Observations from other observatories were also included in the analyses and discussions.

In 1962 , with the realization that both observationally and theoretically the variation of latitude was only one aspect of the more general polar motion, the service was reorganized as the International Polar Motion Service. The Central Bureau of the new service was set up at Mizusawa, Japan, and carried on its work with the collaboration of 32 stations in 19 countries, using observations obtained with photographic zenith telescopes and (Danjon) astrolabes, as well as with the older instruments. Due to the recent participation of three more stations, one of which is in Ecuador, 35 stations in 20 countries are collaborating at present. They are: Algiers, Belgrade, Besançon, Blagoveshchensk, Borowiec, Brera (Milan), Carloforte, Dresden, Engelhardt, Gaithersburg, Greenwich, Hamburg, Irkutsk, Kitab, La Plata, Mizusawa, Mount Stromlo, Neuchâtel, Ottawa, Paris, Poltava, Potsdam, Prague, Pulkovo, Quito, Richmond, San Fernando, Santiago, Tokyo, Uccle, Ukiah, U.S.S.R. (Main Observatory), Warsaw, Washington and $\mathrm{Zi}-\mathrm{Ka}-\mathrm{Wei}$.

Preliminary summaries of the results of latitude observations at the collaborating stations and of the preliminary co-ordinates of the instantaneous pole in the new system 1900-05 of the ILS, derived from the results of the five ILS stations, are published each month in the "Monthly Notes of the IPMS" as a rapid service.

The original data for the latitude observations in detail, and the various results derived from 
them, are given in the "Annual Report of the IPMS", the first volume of which was published in 1964 for the year 1962 . Those for 1963 and 1964 should have been published in 1965 .

Brief reports of the IPMS for $1962 \cdot 0-1963.2$ and $1963 \cdot 0-1964 \cdot 2$ were submitted respectively to the thirteenth General Assembly of the IUGG, held in Berkeley (I963) and the twelfth General Assembly of the IAU, held in Hamburg (1964).

Copies of these reports or notes are available on request to the Director of the IPMS to anyone who is interested.

Co-ordinates of the instantaneous pole, derived from the results of the five ILS stations with reference to the new system of the ILS (1900-05) are given below.

Table I

\begin{tabular}{|c|c|c|c|c|c|c|c|c|}
\hline $\begin{array}{c}\text { Besselian } \\
\text { Year }\end{array}$ & $x$ & $y$ & $\begin{array}{c}\text { Besselian } \\
\text { Year }\end{array}$ & $x$ & $y$ & $\begin{array}{c}\text { Besselian } \\
\text { Year }\end{array}$ & $x$ & $y$ \\
\hline $1962 \cdot 00$ & -"009 & $+" 297$ & $1963 \cdot 00$ & $-" 121$ & $+" 248$ & $1964 \cdot 00$ & $-"{ }_{171}$ & $+" 121$ \\
\hline .05 & +.008 & +309 & .05 & $-\cdot \operatorname{IIg}$ & $+\cdot 295$ & .05 & $-\cdot 207$ & $+\cdot 167$ \\
\hline '10 & +.027 & +314 & . 10 & $-\cdot 105$ & $+\cdot 329$ & . 10 & $-\cdot 192$ & $+\cdot 23 I$ \\
\hline - I 5 & $+\cdot 047$ & $+\cdot 312$ & 15 & -.076 & $+\cdot 356$ & 15 & $-\cdot 166$ & $+\cdot 297$ \\
\hline .20 & +.071 & +304 & .20 & -.038 & $+\cdot 376$ & 20 & $-\cdot{ }^{3} 8$ & $+\cdot 349$ \\
\hline$\cdot 25$ & +.095 & +290 & .25 & +.009 & $+\cdot 388$ & .25 & -.100 & $+\cdot 4 \mathrm{I}$ \\
\hline 30 & $+\cdot 120$ & $+\cdot 27 I$ & 30 & +.070 & $+\cdot 387$ & 30 & -.056 & $+\cdot 446$ \\
\hline 35 & $+\cdot 144$ & $+\cdot 246$ & 35 & $+\cdot 134$ & $+\cdot 375$ & 35 & -.001 & $+\cdot 459$ \\
\hline 40 & $+\cdot 162$ & +.214 & 40 & $+\cdot I 9 I$ & $+\cdot 349$ & 40 & +.075 & $+\cdot 45$ \\
\hline$\cdot 45$ & $+\cdot 173$ & $+\cdot 175$ & 45 & $+\cdot 239$ & $+\cdot 307$ & $\cdot 45$ & $+\cdot 159$ & +43 \\
\hline 50 & $+\cdot 171$ & $+\cdot 132$ & 50 & $+\cdot 274$ & $+\cdot 25 I$ & 50 & $+\cdot 212$ & +40 \\
\hline$\cdot 55$ & $+\cdot 157$ & +.092 & 55 & $+\cdot 301$ & $+\cdot 193$ & $\cdot 55$ & $+\cdot 240$ & $+\cdot 34 \mathrm{I}$ \\
\hline .60 & $+\cdot 128$ & +.068 & 60 & $+\cdot 28 \mathrm{I}$ & $+\cdot \times 39$ & 60 & $+\cdot 242$ & +27 \\
\hline 65 & +.094 & +.060 & 65 & $+\cdot 237$ & $+\cdot 09 I$ & $\cdot 65$ & $+\cdot 239$ & $+\cdot 21$ \\
\hline 70 & +.056 & +.067 & 70 & $+\cdot 176$ & +.046 & 70 & +.255 & $+\cdot I 6$ \\
\hline 75 & +.017 & +.083 & 75 & $+\cdot 112$ & $+\cdot 008$ & 75 & $+25 \mathrm{I}$ & $+\cdot 12$ \\
\hline .80 & -.019 & $+\cdot 104$ & .80 & $+\cdot .048$ & -.022 & .80 & $(+.220$ & $+\cdot 82)$ \\
\hline$\cdot 85$ & -.054 & $+\cdot 128$ & $\cdot 85$ & -.011 & +.005 & $\cdot 85$ & $(+\cdot 155$ & $+\cdot 56$ \\
\hline .90 & -.086 & $+\cdot 160$ & .90 & -.069 & +.043 & & & \\
\hline$\cdot 95$ & $-\cdot 110$ & +200 & 95 & $-\cdot 122$ & $+.08 I$ & & & \\
\hline
\end{tabular}

\section{The "Quarterly Bulletin on Solar Activity"}

Address: Eidgenössische Sternwarte, Schmelzbergstrasse 25, Zürich 6, Switzerland.

Director: Professor M. Waldmeier.

The "Quarterly Bulletin on Solar Activity" was founded by IAU Commission ro in I928. Its former title in use until 1939 was: "Character Figures of Solar Phenomena", and, up to the present time, 146 issues have appeared. At the beginning, the Quarterly Bulletin contained sunspot relative-numbers as well as character figures for bright and dark flocculi (plages and filaments). However, since the minimum of solar activity in 1933 , lists of chromospheric eruptions (flares) have also been included and, as from 1939, the times of solar patrol in the monochromatic light of the $\mathrm{H} \alpha$ line have also been published. Thus, the Quarterly Bulletin provides flare data for three complete solar cycles, which are of great importance for many geophysical studies. In 1947 the information given in the Bulletin was still further enlarged by the addition of the intensities of the coronal emission lines, especially those of the lines $5303 \AA$ and $6374 \AA$, and by the inclusion of the measurements of the solar radio emission. The radio data comprise daily flux measurements, the variability and the location of emissive regions, bursts and the spectral classification of the solar activity in the radio-frequency region. 
At present the "Quarterly Bulletin on Solar Activity" collects and summarizes data furnished by about 100 observatories all over the world.

All further information can be obtained from Professor M. Waldmeier at the address given above.

\section{International Ursigrams and World Days Service}

(a) Aims and structure of IUWDS

(i) Name. The International Ursigram and World Days Service (IUWDS) is a permanent service of the International Scientific Radio Union (URSI) in association with the International Astronomical Union (IAU) and the International Union of Geodesy and Geophysics (IUGG). The IUWDS adheres to the Federation of Astronomical and Geophysical Services (FAGS).

(ii) Terms of reference. The service aims to provide information rapidly to the world scientific community to assist in the planning, co-ordination and conduct of scientific work in the relevant disciplines.

These aims will be achieved by the

$(\alpha)$ advance specification of regular World Days, World Geophysical Intervals and other periods of geophysical interest, which will be published annually in World Geophysical Calendars;

$(\beta)$ collection, co-ordination, interchange and distribution by rapid means of selected current observations and information of immediate significance to geophysical and space research and the provision of suitable interchange synoptic codes;

$(\gamma)$ specification on a current schedule, by a World Warning Agency, of Solar Activity and Geophysical Alerts and occasionally special World Intervals;

$(\delta)$ preparation and publication of periodic post-facto calendar records of significant indices outstanding solar and geophysical events;

$(\epsilon)$ undertaking of similar activities in co-operation with the participating scientific unions or other international scientific bodies.

(iii) Regional structure. In view of $\{\ddot{i} \beta$ and $\ddot{i} \gamma$ there shall be Regional Ursigrams and World Days Services in each of the geographical regions. In 1962 there were four such regions: (I) Europe and Africa, (2) western hemisphere, (3) western Pacific, (4) Eurasia.

In each region, communication facilities are provided by the respective national communications services for the collection and distribution of current observations and information. One of the centres engaged in this work shall be designated as the Regional Warning Center, through which centre the interchange of data between the regions is accomplished. Other centres in this region may be called Associate Regional Warning Centers.

One of the Regional Warning Centers shall be designated as the World Warning Agency which declares the world-wide alerts and special observing periods, with the active co-operation of the other Regional Warning Centers.

In each region there shall be a Regional Ursigram and World Days Committee.

\section{(b) Administration}

The IUWDS is administered by a Steering Committee including representatives of URSI, IAU, IUGG, and of Regional Committees, a secretary and a deputy secretary, and the General Secretary of URSI (ex officio). Present officials of the Steering Committee are Dr A. H. Shapley, Chairman, Mr L. D. de Feiter, Secretary, Miss J. V. Lincoln, Deputy Secretary. The IAU representative is Dr R. Michard. 
The activities of the Service are made up of the activities in various geographical regions, each being co-ordinated by a Regional Committee.

(c) Activities of IUWDS of special interest to astronomers

(i) Through the Regional Warning Centers (RWC), the Service collects daily information on solar-geophysical phenomena from observing stations. The contribution of astronomers in providing data is very welcome, particularly as regards observations of solar flares.

(ii) Through the data summaries and alerts which are distributed by various fast means from the RWCs, astronomers may be kept informed of the state of solar activity (general level and special events) and also of geophysical events. The IUWDS will always try to answer particular needs about fast information, or special types of alerts.

(iii) The IUWDS co-operates with the IAU Bureau of Astronomical Telegrams in distributing information on comets, novae, etc. The telegrams issued by the Bureau (Smithsonian Astronomical Observatory) are forwarded to RWCs and thence to interested scientists.

Astronomers needing information on the facilities offered by IUWDS should approach the RWC in their geographical area. The IAU representative (presently R. Michard, Observatoire de Paris, 92-Meudon, France) will also be glad to answer inquiries.

(d) List of Regional Warning Centers

(i) RWC western hemisphere and IUWDS World Warning Agency

Mail: North Atlantic Radio Warning Service, Box 178 , Ft. Belvoir, Virginia, U.S.A.

Telephone: Washington $765-64$ I I or $765-843^{6}$.

Cable and Radiogram: AGIWARN Washington.

Telex: 24386.

Supervisor: Miss J. V. Lincoln (CRPL, Boulder, Colorado, U.S.A.).

In charge: $\mathrm{K}$. D. Boggs.

(ii) Western Europe (there are three RWCs)

\section{Nera}

Mail: Radio Receiving Station NERA, Nederhorst den Berg, The Netherlands.

Telegraph: AGI Nederhorstdenberg.

Telex: Amsterdam I2308.

Supervisor: J. C. Dito (PTT Leidschendam).

In charge: $\mathrm{H}$. Van Lohuizen.

Paris

Mail: Service des Ursigrammes et Jours Mondiaux, Centre National d'Etudes des Télécommunications, I96 rue de Paris, 92-Bagneux, France.

Telegraph: CNETAGI Bagneux.

Telex: Paris 25312.

Telephone: 2533 II 7 .

Supervisor: Dr P. Simon (Observatoire de Meudon).

In charge: Miss N. Lordel.

Darmstadt

Mail: FTZ Arbeitsgemeinschaft Ionosphaere, Rheinstrasse r ro, 6r Darmstadt, Federal Republic of Germany.

Telegraph: IONOSPHAERE DARMSTADT.

Telex: 4-I8929I.

Telephone: Darmstadt 83-2350. 
Supervisor: B. Beckmann.

Assistant: A. Ochs.

In charge: G. Richter.

(iii) Eurasia

Mail: Institute of Terrestrial Magnetism, Ionosphere and Radio Propagation (IZMIRAN), Leninskii r-p, P.O. Vatutenkii, Moscow, U.S.S.R.

Telegraph: NIZMIR MOSCOW.

Telephone: B2-19-21, 6-03-50.

Supervisor: Mrs R. A. Zevakina.

In charge: Mrs L. N. Liakhova.

(iv) Western Pacific

Mail: Radio Research Laboratories, Kokubunji P.O., Koganei-shi, Tokyo, Japan.

Telegraph: DEMPA KOKUBUNJI.

Supervisor: Dr H. Uyeda.

In charge: T. Takiguchi.

There are also Associate Regional Warning Centres co-operating in the Service, in Sydney, Anchorage, Stockholm and Prague.

D. THE CENTRAL BUREAU FOR ASTRONOMICAL TELEGRAMS

Smithsonian Astrophysical Observatory, Cambridge, Massachusetts 02138, U.S.A. Director of the Bureau: Dr O. Gingerich

\section{General Information}

For nearly a century, astronomers have maintained a telegraph and cable network for rapid communication of such celestial news as the discovery of comets and novae. When the International Astronomical Union was organized in 1922, the Central Bureau for Astronomical Telegrams was placed under its jurisdiction (through Commission 6 of the Union) and established at the Copenhagen Observatory. At the Twelfth General Assembly of the IAU in Hamburg (August 1964), Mr K. A. Thernöe, who had served as Director during the previous four years, requested that the Central Bureau be transferred, and the IAU asked the Smithsonian Astrophysical Observatory, Cambridge, Massachusetts 02138 , U.S.A., to provide new headquarters for the Central Bureau beginning I January 1965 .

Telegrams or cables can be received any time of day or night at the Smithsonian Observatory. The cable address is SATELLITES, NEWYORK, and the Western Union address for astronomers in North America is RAPID SATELLITE, CAMBMASS. In North America, telegrams are sent out collect via Western Union to any astronomers agreeing to pay for the messages. The larger share of other addresses are reached through the Regional Warning Centers of the International Ursigram and World Days Service (the AGIWARN network), an active legacy of the International Geophysical Year. The financial arrangements depend on the particular Regional Warning Centers, whose addresses appear below:

France, British Isles, Spain, Portugal, Italy, Greece, Middle East, North Africa:

Dr P. Simon, Observatoire de Paris, Section d'Astrophysique, 92-Meudon, France.

Germany, Austria, Belgium, Denmark:

G. Richter, FTZ Arbeitsgemeinschaft Ionosphäre, Rheinstrasse I10, 6I Darmstadt,

Federal Republic of Germany.

Sweden, Norway, Finland:

Per Akerlind, Board of Swedish Telecommunications, Stockholm I6, Sweden. 
Netherlands:

H. Van Lohuizen, Radio Receiving Station NERA, Nederhorst den Berg, The Netherlands.

Czechoslovakia:

Mr Priska, Czechoslovakian Academy of Sciences, Geophysical Institute, Ionosphere Department, Praha, Sporilov, Czechoslovakia.

U.S.S.R., People's Republic of China, Poland, Hungary, Rumania, Bulgaria:

Mrs L. N. Liakhova, Institute of Terrestrial Magnetism, Ionosphere and Radio Propagation, (IZMIRAN), Leninskii r-p, P.O. Vatutenki, Moscow, U.S.S.R.

Japan:

Dr H. Uyeda, Radio Research Laboratories, Ministry of Posts and Telecommunications, Kokubunji P.O., Koganei-shi, Tokyo, Japan.

Australia, New Zealand:

Mr F. E. Cook, Ionospheric Prediction Service, Commonwealth Centre, Elizabeth Street, Sydney, N.S.W. Australia.

It is not necessary for observatories to receive all the "astrograms"; instead, subscribers can specify only the desired standard categories (the identifying telegram code word appears in the second column):

A. ALPHA Comet discoveries, $m \leqslant 12$.

B. BETA Comet discoveries, $m>\mathbf{I} 2$.

C. CHARLY Comet observations and brief finding ephemerides (primarily for observers).

D. DELTA Precision positions, orbits and ephemerides (primarily for computers).

E. ECHO Novae or supernovae, $m \leqslant \mathbf{1 2}$.

F. FRANCE Novae or supernovae, $m>\mathrm{x} 2$.

G. GAMMA Planetary or lunar phenomena.

H. HOTEL All others, including unusual fast-moving objects, spectroscopic binaries, etc.

Almost all the messages are transmitted according to a telegraphic cipher code. In accordance with the wishes of Commission 6 , the code has been revised; this new revised code, together with examples, is appended to this notice. The principal changes are:

(a) Equinox explicitly included in the code;

(b) Time of observation in decimals of day, which also allows more accuracy (to about a second);

(c) A contiguous ordering of data in the accurate position codes;

(d) A more precise description of magnitudes;

(e) No explicit distinction in the form of circular, elliptical and parabolic orbital elements;

$(f)$ Orbital elements are now in degrees and decimals instead of degrees and minutes.

For unusual messages that cannot be cast in the standard coded form, observers are nevertheless urged to include a checksum of all numerical material in the telegram.

In addition to the astrograms, the Central Bureau maintains an even wider coverage by means of its postcard Circulars, which are issued irregularly about $5^{\circ}$ times a year. These contain confirmations of the telegrams, predicted ephemerides for comets and unusual asteroids as well as observed positions, observations of novae and supernovae, and other astronomical information that requires rapid dissemination. About 600 observatories and advanced amateurs subscribe to the Circulars. 
The Circulars are available by advance subscription only, for $5 \circ$ or 100 issues (not corresponding to a calendar year). These financial arrangements are entirely separate from the telegrams. The present subscription rates, shown below, depend on the destination and mode of transport.

$\begin{array}{cr}\text { United States, } & \text { Other } \\ \text { Canada, Mexico } & \\ \$ 5.00 & \$ 6.5^{\circ} \\ 9.5^{\circ} & 12.5^{\circ} \\ \$ 6.00 & \$ 7.5^{\circ} \\ 11.5^{\circ} & 14.5^{\circ}\end{array}$

An additional fee of $\$ 0^{\circ} 50$ is charged when invoices are required. All observatories and astronomers are urged to work directly with the Central Bureau rather than through dealers. Checks, bank drafts, or money orders should be made payable to the "Central Bureau for Astronomical Telegrams".

\section{APPENDIX I. ASTRONOMICAL TELEGRAM CODE}

First groups for all telegrams

\section{DISCOVERER OBJECT OBSERVER AAAAB}

I. The name of the discoverer(s) and/or other designation, such as year and letter for a comet, constellation for a nova, galaxy for a supernova ( $N=N G C, I=I C, M=$ Messier) etc.

2. The type of object (comet, nova, variable star = VSTAR, etc.).

3. Name of observer(s) and/or computer(s).

4. $\mathrm{AAAA}=$ Equinox.

$\mathrm{B}=\mathrm{I}$ for an approximate position;

$=2$ for an accurate position;

$=3$ for orbital elements of an object moving around the Sun;

$=4$ for an ephemeris.

Note: when an ephemeris follows the elements, code word 4 is replaced by the word EPHEMERIS, and the epoch of the ephemeris is assumed to be the same as the elements. See example 5 .

\section{Middle groups for a position}

Approximate ABBCC DDDDD EEFFF HJJKK NMMP RTTTT UVVWW Accurate ABBCC DDDDD EEFFG GGGHJ JKKLL LNMMP RTTT'T UVVWW

5. Date of observation:

$A=$ final digit of year;

$\mathrm{BB}=$ month (OI $=$ January $, \ldots, 12=$ December $) ;$

$\mathrm{CC}=$ day (U.T.).

6. DDDDD = Time of observation in decimals of a day (U.T.).

7. Approximate:

Right ascension $\mathrm{EE}^{\mathrm{h}} \mathrm{FF} \mathrm{m} \mathrm{F}$

Declination $\quad \mathrm{H} \mathrm{JJ}^{\circ} \mathrm{KK}^{\prime}$ 


\section{Accurate:}

Right ascension $\mathrm{EE}^{\mathrm{h}} \mathrm{FF}^{\mathrm{m}} \mathrm{GG} \mathrm{GGG}$

Declination $\quad \mathrm{H} \mathrm{JJ}^{\circ} \mathrm{KK}^{\prime} \mathrm{LL}{ }^{\prime \prime} \mathrm{L}$

$\mathrm{H}=$ sign, $2=$ positive, $\mathrm{I}=$ negative.

8. $\mathrm{Y}=\mathrm{Y}$, the character for a nonsignificant digit.

$\mathrm{N}=$ type of magnitude;

$\mathrm{N}=\mathrm{I}$ for total (integrated) magnitude for a comet;

$=2$ for magnitude of the nuclear condensation for a comet;

$=3$ for visual

$=4$ for photographic for objects of stellar appearance (including minor planets);

$=5$ for photovisual

$\mathrm{MM}=$ magnitude; if the magnitude is negative, add Ioo;

$\mathrm{P}=$ appearance, according to the table below, or if the object is not a comet, $\mathrm{P}=$ tenth of a magnitude.

Stellar appearance

Nothing reported about

appearance of the object itself

Object diffuse, without central

condensation or nucleus

Object diffuse, with central

condensation or nucleus

\section{Nothing reported} about tail

$\circ$

I

4

7
Tail $<\mathbf{I}^{\circ}$

Tail $>\mathrm{I}^{\circ}$

9. Daily motion (omitted if unknown or irrelevant)

Right ascension R TTm'TT

Declination $\mathrm{U} \mathrm{VV}^{\circ} \mathrm{WW}^{\prime}$

$\mathrm{R}, \mathrm{U}=$ sign, $2=$ positive, $\mathrm{I}=$ negative.

For SUPERNOVAE, the offset from the nucleus in seconds of arc.

R TTT'T" R: 2 = east, $\quad \mathrm{I}=$ west

U VVWW" $U: 2=$ north, $\quad I=$ south

\section{Middle groups for orbital elements}

\section{ABBCC DDDEF GGGGG HHHHH JJJJJ KKKKK LLLLL}

5. Date of perihelion passage:

$A=$ final digit of year;

$\mathrm{BB}=$ month $(\mathrm{Or}=$ January, $\ldots, \mathbf{1 2}=$ December $) ;$

$\mathrm{CC}=$ day.

6. $\mathrm{DDD}=$ time of perihelion passage (E.T.).

$\mathrm{E}=$ length of the orbital arc in days between the first and last position used for the computation, rounded to the nearest integer number of days; $0=$ an arc of 10 days or more.

$\mathrm{F}=$ the number and quality of the observations on which the computation is based, or by which the elements have been checked, according to the following table:

Less than three accurate positions*

Three accurate positions

More than three accurate positions

$>$\begin{tabular}{rrr}
\multicolumn{3}{c}{ Maximum residuals } \\
5 & $\mathrm{I}^{\prime \prime}-5^{\prime \prime}$ & $\leqslant \mathrm{x}^{\prime \prime}$ \\
$\mathrm{I}$ & 2 & 3 \\
4 & 5 & 6 \\
7 & 8 & 9
\end{tabular}

* Or other factors decreasing the reliability of the orbit such as approximate, doubtful or unsatisfactorily distributed positions. 
7. GGG. GG $=\omega$;

HHH. $\mathrm{HH}=\Omega$;

JJJ. JJ $=\mathrm{i}$;

K. $\mathrm{KKK}=\mathrm{q}$ in A.U.

L. $\mathrm{LLLL}=\mathrm{e}$.

If the orbit is parabolic, the last group of five digits may be omitted.

8-9. Non-existent for orbital elements; go on to final groups.

Middle groups for ephemerides

ABBCC (EEFFF HJJKK DXXXX RYYYY) abbcc

5. Date of first line of an ephemeris:
$A$ = final digit of year;
$\mathrm{BB}=$ month;
$\mathrm{CC}=$ day.

6. It is understood that ephemerides are given for $\mathrm{O}^{\mathrm{h}}$ E.T.

7. Right ascension EE ${ }^{\text {hFFmF }}$

Declination $\quad \mathrm{H} \mathrm{JJ}^{\circ} \mathrm{KK}^{\prime}$

$H=$ sign, $2=$ positive, $\mathbf{I}=$ negative.

8. $\mathrm{X} . \mathrm{XXX}=$ geocentric distances in A.U., prefixed by a $\mathrm{D}$;

Y. YYY = heliocentric distances in A.U., prefixed by an R.

Groups 7 (and 8 ) are repeated as often as necessary to complete the ephemeris. Groups 8 are considered mandatory, but may be omitted for some lines (see example 5).

9. abbcc is the date of the last line of an ephemeris, in the same form as before.

\section{Final groups for all telegrams}

\section{ZZZZZ COMMUNICATOR}

Iо. ZZZZZ = the last five figures of the sum of all the groups of digits including and following group 4 (equinox and type). If a digit is not significant, it is replaced by a $\mathrm{X} ; \mathrm{X}, \mathrm{D}$ and $\mathrm{R}$ are counted as zero in the summation.

II. The name of the communicator.

\section{Examples}

I. ALCOCK COMET VAN BIESBROECK I950I $30323 \quad 29688 \quad 19302 \quad 24924$ XIo85 IOI2X 2001254955 YERKES.

The Yerkes Observatory reports that van Biesbroeck has observed Comet Alcock as follows:

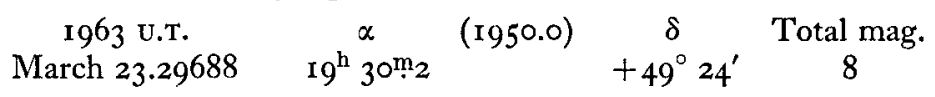

Object diffuse without central condensation or nucleus, tail less than $I^{\circ}$. Daily motion: in R. A. $-\mathrm{r}_{2}$, in December $+12^{\prime}$.

2. WHIPPLE COMET ROEMER I9502 20504420962040274910721308220031744 USNO

The United States Naval Observatory reports that Roemer has observed periodic Comet Whipple as follows:

$$
\begin{array}{ccccc}
\text { I962 U.T. } & \alpha & (\text { I950.0) } & \delta & \text { Mag. } \\
\text { May 4.42096 } & 20^{\text {h }} 40^{\text {ml }} 27^{8} .49 & & -7^{\circ} 21^{\prime} 30^{\prime \prime} \cdot 8 & 20
\end{array}
$$

Stellar appearance, nothing reported about tail. 
3. CANDY COMET CANDY $19503102085833^{8}$ I3625 I7656 I 50921064045062 CANDY.

Candy reports that he has calculated parabolic elements for his comet as follows:

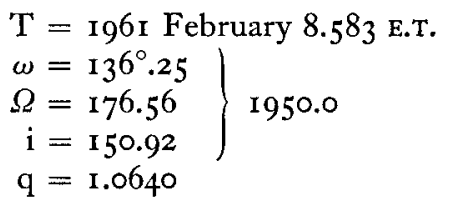

The elements are based on three accurate positions with residuals between $I^{\prime \prime}$ and $5^{\prime \prime}$, and over an arc of 3 days.

4. DAHLGREN HERCULES NOVA DAHLGREN r9601 30206 XXXXX ${ }_{1813}$ 24I 50 X3०39 95126 STOCKHOLM.

The Stockholm Observatory reports that Dahlgren has discovered a nova in Hercules as follows

$\begin{array}{ccccc}\text { I963 } & \alpha & (1960.0) & \delta & \text { Mag. } \\ \text { February 6 } & \mathrm{I}^{\mathrm{h}} \mathrm{I} 3^{\mathrm{m}} & +4 \mathrm{I}^{\circ} 5^{\prime} & 3^{*} 9\end{array}$

Magnitude visual.

5. KEARNS KWEE I963D COMET MARSDEN I9503 31206 $95^{109}$ I 3 I I 73 I 54300899 22133 04866 I8376 EPHEMERIS 40215 06066 22844 Di557 R2284 06129 2274306218 22645 Di799 R2327 06327 $2255^{\circ} 0645322456$ D2074 R2380 40326 37393 THERNOE.

Thernoe reports that Marsden has calculated elliptical elements (based on more than three accurate positions with maximum residuals $I^{\prime \prime}$, over an arc exceeding 10 days), and an ephemeris for periodic comet Kearns-Kwee (1963d) as follows:

$$
\begin{aligned}
& \mathrm{T}={ }_{1963} \text { December 6.95 I E.T. } \\
& \omega=131^{\circ} \cdot 17 \\
& \left.\begin{array}{rr}
\Omega= & 3^{1} 5.43 \\
\mathrm{i}= & 8.99
\end{array}\right\} \text { I950.0 } \\
& \mathrm{q}=2 \cdot 2133 \\
& \mathrm{e}=0.4866
\end{aligned}
$$

\begin{tabular}{|c|c|c|c|c|c|}
\hline $\begin{array}{c}\text { I964 E.T. } \\
\text { February I } 5^{\circ} \mathrm{O}\end{array}$ & $6^{\mathrm{h}} \stackrel{\alpha}{\circ 6^{\mathrm{m}} 6}$ & $\left(195^{\circ} \circ\right)$ & $\begin{array}{c}\delta \\
+28^{\circ} 44^{\prime}\end{array}$ & $\begin{array}{c}\Delta \\
\times \cdot 557\end{array}$ & $\begin{array}{c}r \\
2 \cdot 284\end{array}$ \\
\hline 25.0 & $6 \quad 12 \cdot 9$ & & 2743 & & \\
\hline $6 \cdot 0$ & $6 \quad 21 \cdot 8$ & & 2645 & $I \cdot 799$ & $2 \cdot 327$ \\
\hline $16 \cdot 0$ & $6 \quad 32 \cdot 7$ & & $255^{\circ}$ & & \\
\hline $26 \cdot 0$ & $645 \cdot 3$ & & $+245^{6}$ & $2 \cdot 074$ & $2 \cdot 380$ \\
\hline
\end{tabular}

6. RSOPH VSTAR FERNALD 1900 I 80714 IXXXX $1745^{8}$ ro640 X $306 \mathrm{X}_{40873}$ AAVSO.

The American Association of Variable Star Observers reports that Fernald has observed the variable star RS Ophiuchi as follows:

$$
\begin{array}{lcccc}
\text { I958 U.T. } & \alpha & (\text { I } 900 \cdot 0) & \delta & \text { Vis. Mag. } \\
\text { July I } 4 \cdot \mathrm{I} & \mathrm{I} 7^{\mathrm{h}} 45^{\mathrm{m} \cdot 8} & & -6^{\circ} 4 \mathrm{O}^{\prime} & 6
\end{array}
$$

7. FACE-ON SPIRAL SUPERNOVA ZWICKY 19501 50226 XXXXX 10370 12739 $\mathrm{X}_{41} 140200172002937023$ SCHMIDT.

Schmidt reports the observation by Zwicky of a supernova in an anonymous face-on spiral as follows:

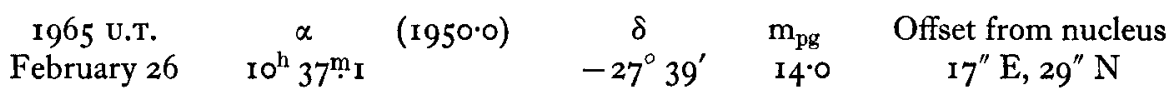


8. WILD N3913 SUPERNOVA ANTAL I9502 30607 928XX I 1480001255374274139 82395 SKALNATE PLESO.

The Skalnate Pleso Observatory reports that Antal has observed Wild's supernova in NGC 3913 as follows:

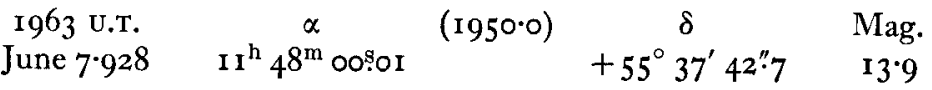

Magnitude photographic.

APPENDIX II. TELEGRAM CODE FOR COMET POSITION

\begin{tabular}{|l|l|l|}
\hline DISCOVERER & OBJECT & OBSERVER \\
\hline & & \\
\hline
\end{tabular}

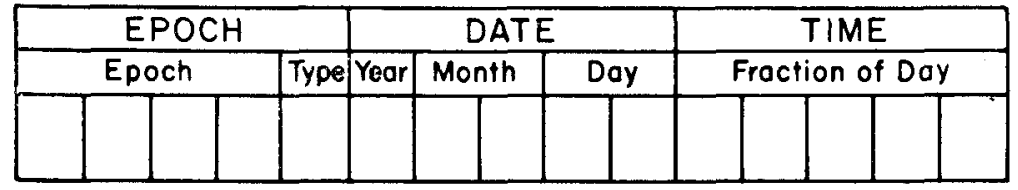

APPROXIMATE :

\begin{tabular}{|c|c|c|c|c|c|c|c|c|}
\hline \multicolumn{2}{|c|}{ R. A. } & \multicolumn{3}{|c|}{ DEC. } & \multicolumn{4}{|c|}{ PHYSICAL } \\
\hline $\mathrm{Hr}$ & Min & \pm & 0 & 1 & & Type & Mog & Desc \\
\hline & & & & & $x$ & & & \\
\hline
\end{tabular}

ACCURATE :

\begin{tabular}{|c|c|c|c|c|c|c|c|c|c|}
\hline \multicolumn{2}{|r|}{ R. A. } & & & \multicolumn{3}{|c|}{ DEC. } & \multicolumn{3}{|c|}{ PHYSICAL } \\
\hline $\mathrm{Hr}$ & Min & Seconds & \pm & 0 & 7 & "I & Type & Mag. & Desc \\
\hline & & 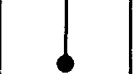 & & & & & & & \\
\hline
\end{tabular}

\begin{tabular}{|l|l|l|l|l|l|l|l|l|l|l|l|l|l|l|l|}
\hline DAILY MOTION R. A. & DAILY MOTION DEC & \multicolumn{5}{|c|}{ CHECK SUM } & COMMUNICATOR \\
\hline \pm & \multicolumn{3}{|c|}{ Min } & \pm & \pm & C & & \\
\hline & & & & & & & & & & & & & & & \\
& & & & & & & & & & & & & & & \\
\hline
\end{tabular}

$t=2$

$-=1$ 